\title{
2018
}

Tom XX

http://dx.doi.org/10.18778/2080-8313.20.02

Magdalena Ujma

(Uniwersytet Opolski) $^{*}$

\section{SPUŚCIZNA POJEZUICKA W ZASOBACH CENTRALNEGO PAŃSTWOWEGO ARCHIWUM HISTORYCZNEGO WE LWOWIE**}

\begin{abstract}
Streszczenie. W zasobach Państwowego Archiwum Historycznego Ukrainy we Lwowie źródła odnoszące się do jezuitów dotyczą różnych części Galicji, a w niektórych przypadkach także terenów poza jej granicami. Większość jednostek archiwalnych zawierających dokumenty z okresu kasat zakonu nie jest powszechnie znana, a niektóre z nich prawdopodobnie nigdy nie były wykorzystywane. Zaprezentowane w artykule dokumenty mogą zainteresować historyków sztuki, a także historyków kultury materialnej lub historyków medycyny. Część z nich może okazać się przydatna także w badaniach nad przed- i pokasatowym stanem posiadania jezuitów w zaborze austriackim i poza jego granicami. Szeroki zakres chronologiczny i bogactwo tego materiału prowadzą do wniosku, że dobrze odzwierciedla on kolejne etapy historii jezuickiej po rozwiązaniu zakonu w $1773 \mathrm{r}$. Wiele dokumentów dotyczy też okresu po jego przywróceniu w $1814 \mathrm{r}$. Jego delegalizacja w 1848 r. i droga do zniesienia jezuitów w 1853 r. są dobrze udokumentowane. Zachowane zasoby nie muszą być oczywiście w pełni niezawodne. Mogą również nie odzwierciedlać faktycznego stanu posiadania w okresie przed rozwiązaniem. Ważne jest to, że pozwalają przynajmniej na częściową rekonstrukcję wyposażenia kościołów, kolegiów, aptek lub klasztorów. Dokumenty te zawierają również listy mnichów i dyskusję na temat zapewnienia im środków utrzymania. Dzięki nim otrzymujemy także przestrzenny obraz ewolucji działek pojezuickich, stopniowo łączących się z modernizowanym w XIX w. organizmem miejskim.
\end{abstract}

Słowa kluczowe: Jezuici, Lwów, kasaty, klasztory.

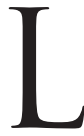
wów był miejscem aktywnej, religijnej i edukacyjnej działalności Towarzystwa Jezusowego. Z miastem nad Pełtwią wiąże się wiele znanych nazwisk, między innymi urodzonego tutaj polskiego orientalisty, kartografa, przyrodnika i misjonarza w Chinach Michała Piotra Boyma ${ }^{1}$, a także pisarza,

${ }^{*}$ Uniwersytet Opolski, Instytut Historii, Katedra Historii Nowożytnej, e-mail: magdau.opole@ interia.pl.

** Praca naukowa finansowana w ramach programu Ministra Nauki i Szkolnictwa Wyższego pod nazwą „Narodowy Program Rozwoju Humanistyki” w latach 2012-2016. Scientific work financed by the Ministry of Science and Higher Education under the name of the „National Programme for the Development of Humanities" in the years 2012-2016.

${ }^{1}$ Zob. m.in. E. Kajdański, Michat Boym - ostatni wysłannik dynastii Ming, Warszawa 1988; idem, Michał Boym - Ambasador Państwa Środka, Warszawa 1999. 
kaznodziei i wykładowcy Kaspra Drużbickiego ${ }^{2}$. Superiorem domu jezuitów we Lwowie, a zarazem pisarzem, teologiem i królewskim kaznodzieją był słynny Marcin Laterna ${ }^{3}$. Ormiańskim pochodzeniem odznaczał się lwowianin, filozof i pisarz oświeceniowy, Grzegorz Piramowicz ${ }^{4}$. Zasoby Centralnego Państwowego Archiwum Historycznego Ukrainy we Lwowie (dalej: CPAH-Lw.) składają się jednak ze źródeł związanych z różnymi częściami Galicji, dzięki czemu badacz zyskuje sposobność prześledzenia działalności jezuitów w niemal całym zaborze austriackim, a w niektórych przypadkach także poza jego granicami.

Bibliografia omawiająca sytuację jezuitów w drugiej połowie XVIII i w pierwszej połowie XIX w. obfituje zarówno w nadal cenne, choć starsze już pozycje, jak i w nowe w istotny sposób poszerzające naszą wiedzę na temat kasat i konfiskat majątku zakonu. Dzieje jezuitów, w tym również jezuitów galicyjskich, pozostawały w kręgu zainteresowań Stanisława Załęskiego SJ, który poświęcił dużo uwagi działalności tego zakonu w dawnej Polsce ${ }^{5}$. Nie zamieścił on jednak w poświęconej jezuitom obszernej monografii szczegółowych danych na temat wykorzystanych przez siebie rękopisów przechowywanych w Archiwum Miejskim Lwowa, a także w bibliotece uniwersyteckiej i lwowskim Ossolineum. Praca ta jest zresztą szeroko zakrojoną syntezą, co musiało się wiązać z selekcją materiału źródłowego. Spod pióra Załęskiego wyszła również monografia kościoła św. Piotra i Pawła we Lwowie ${ }^{6}$ oraz monografia kolegium jezuickiego w Stanisławowie ${ }^{7}$. Na początku XX w. została wydana drukiem biografia św. Stanisława Kostki autorstwa Jana Sygańskiego, w której został uwzględniony również wątek lwowskich jezuitów ${ }^{8}$. W nowszej literaturze przedmiotu wyróżnia się praca Stanisława Obirka poświęcona historii jezuitów począwszy od schyłku panowania Zygmunta Augusta, aż do abdykacji Jana Kazimierza9. Warto także zwrócić uwagę między innymi na opracowanie Grzegorza Łuszczaka poświęcone nauczycielom i wychowawcom jezuickich szkół lwowskich w dobie Rzeczypospolitej przedrozbiorowej ${ }^{10}$. Książka poświęcona Akademii Połockiej

${ }^{2}$ Encyklopedia wiedzy o jezuitach na ziemiach Polski i Litwy (1564-1995), oprac. L. Grzebień SJ przy współpracy zespołu jezuitów, Kraków 1996.

3 S. Cieślak, Marcin Laterna SJ (1552-598). Działacz kontrreformacyjny, Kraków 2003.

${ }^{4}$ Grzegorz Piramowicz i jego epoka, red. K.A. Boreczek i A.A. Witusik, Kurów 2001.

5 S. Załęski, Jezuici w Polsce, t. 1-5, Kraków 1900-1906; idem, OO. Jezuici we Lwowie, Lwów 1880.

${ }^{6}$ Idem, Kościót oo. Jezuitów we Lwowie pod wezwaniem śś. Apostołów Piotra i Pawła, Lwów 1879, s. 19.

${ }^{7}$ Idem, Kolegium jezuickie w Stanisławowie. Szkic historyczny, Nowy Sącz 1896.

8 J. Sygański, Święty Stanisław Kostka, Lwów 1906.

${ }^{9}$ S. Obirek, Jezuici w Rzeczypospolitej Obojga Narodów w latach 1564-1668: działalność religijna, społeczno-kulturalna i polityczna, Kraków 1996.

${ }^{10}$ G. Łuszczak, Nauczyciele $i$ wychowawcy szkót jezuickich we Lwowie 1608-1773, Kraków 2010 . 
znacznie ułatwia natomiast identyfikację nazwisk spornych, pojawiających się w kasacyjnych spisach osobowych ${ }^{11}$.

Znacznie nowszą pozycją jest anglojęzyczna praca Stanisława Obirka omawiająca dzieje jezuitów w Polsce i w Europie wschodniej ${ }^{12}$. Praca Marka Inglota poświęcona położeniu zakonu w Rosji - tak istotna $\mathrm{z}$ uwagi na problem jezuitów napływających do Galicji z Białorusi - omawia to zagadnienie jedynie do $1820 \mathrm{r}^{13}$ Bolesław Kumor - autor artykułu omawiającego wątek powrotu jezuitów na teren Galicji po 1820 r. - umieścił swoje rozważania na tle ówczesnej sytuacji społeczno-politycznej, ale przyjęte przez niego ramy chronologiczne uwzględniają jedynie okres niespełna 10 lat $^{14}$. Wydarzenia krytycznego dla zakonu roku 1820, w oparciu o pamiętnik Jana Galicza, omówiła także Agata Demkowicz ${ }^{15}$. Dłuższy okres przyjął za to Władysław Chotkowski analizując wydarzenia z lat 1820-1848 związane z powrotem jezuitów do Galicji i kasatą ich majątku w czasie Wiosny Ludów ${ }^{16}$.

Autorzy wspomnianej już wyżej encyklopedii poświęconej jezuitom korzystali z zasobów Archiwum Prowincji Polski Południowej Towarzystwa Jezusowego w Krakowie, które zgromadziło reprodukowane źródła z archiwów europejskich. Nie uwzględnili natomiast w bibliografii zbiorów przechowywanych w CPAH-Lw. Można zatem spróbować poddać weryfikacji wniosek o definitywnym zaginięciu większości materiałów archiwalnych, w tym także lustracji kolegiów ${ }^{17}$. Zdecydowana większość jednostek archiwalnych przechowywanych w CPAH-Lw. - zawierających dokumenty z okresu kasat - nie jest szerzej znana. W monografii kolegium jezuickiego w Jarosławiu nie zostały wykorzystane źródła lwowskie ${ }^{18}$. Z kolei, przypominając miejsca przechowywania dokumentów związanych z działalnością jezuitów, Henryka Kramarz nie wymieniła zasobów CPAH-Lw. podkreślając zarazem znaczenie źródeł znajdujących się m.in. w Archiwum Prowincji Małopolskiej Towarzystwa Jezusowego w Krakowie i w Bibliotece Ukraińskiej Akademii Nauk im. W. Stefanyka we Lwowie ${ }^{19}$.

${ }^{11}$ Materyały do dziejów Akademii Połockiej i szkół od niej zależnych, zebrał L.G., Kraków 1905.

${ }^{12}$ S. Obirek, Jesuits in Poland and Eastern Europe, [w:] !e Cambridge Companion to the Jesuits, red. T. Worcester, Cambridge 2008.

13 Инглот М. SJ, Общество Иисуса в Российской Империи (1772-1820 г2.), его роль в повсеместном восстановлении Ордена во всем мире, Moskwa 2004.

${ }_{14}$ B. Kumor, Powrót jezuitów do Galicji, „Folia Historica Cracoviensia” 1994, vol. 2.

${ }^{15}$ A. Demkowicz, Wypędzenie jezuitów z Imperium Rosyjskiego na podstawie fragmentów Wygnańca z Białej Rusi Jana Galicza, „Tematy i Konteksty” 2012, R. 2(7).

${ }_{16}$ W. Chotkowski, Powrót i ponowne zniesienie jezuitów w Galicyi 1820-1848 na podstawie archiwaliów rzadowych, Warszawa 1904.

${ }^{17}$ Cześć materiałów na temat kasaty zakonu jezuitów znajduje się w zbiorach Archiwum Nuncjatury Warszawskiej.

${ }^{18}$ K. Leń SJ, Jezuickie kolegium św. Jana w Jarosławiu 1573-1773, Kraków 2000.

${ }_{19}$ H. Kramarz, Jezuici we Lwowie na przestrzeni wieków (zarys faktografii i perspektywy badawcze), [w:] Jezuici a kultura Polska, Kraków 1993, s. 158. 
Możliwość dokonania porównań szczegółów ujętych w spisach zakonników daje monografia L. Grzebienia poświęcona konwiktowi jezuickiemu we Lwowie ${ }^{20}$. Autor wykorzystał wykaz przechowywany w Archiwum Prowincji Małopolskiej. Odszukany przeze mnie spis przechowywany w CPAH-Lw. czyni wrażenie starannego, choć ma on pewne braki. Nie jest w nim na przykład wymieniony Jan Chrzciciel Frazelin, choć był on związany z konwiktem lwowskim od 1842 r. Nie ma go także w wykazie dotyczącym kolegium tarnopolskiego, choć wiadomo, że pracował tu od $1839 \mathrm{r}^{21}$

Mimo pewnych niedostatków dokumenty przechowywane w CPAH-Lw. wiele wnoszą do naszej wiedzy o jezuitach. Zasługują na uwagę w równej mierze historyków sztuki, jak i badaczy zajmujących się kulturą materialną lub dziejami medycyny. Część zasobów najważniejszego lwowskiego archiwum jest również przydatna w badaniach nad przed- i pokasatowym stanem posiadania jezuitów w Galicji i poza jej granicami. W CPAH - Lw. przechowywanych jest wiele dokumentów pozwalających bliżej poznać nie tylko okres po kasacie zakonu jezuitów w 1773 r., ale i jego późniejsze, burzliwe dzieje. Są one zgromadzone w fondzie (zespole) znanym jako „Namiestnictwo Galicyjskie” (nr 146) ${ }^{22}$. W zbiorze tym znajdują się rozporządzenia, protokoły i supliki z lat 1847-1849. Mają one związek nie tylko z wprowadzaniem w życie samej kasaty, ale także z jednym z jej bezpośrednich skutków - koniecznością zadecydowania o środkach utrzymania dla jezuitów chorych i będących w podeszłym wieku. Korespondencja w tej sprawie była prowadzona w latach 1848-1853 ${ }^{23}$. Częścią wspomnianego tu zespołu archiwalnego są także listy członków Towarzystwa Jezusowego pozwalające ocenić liczbę, wiek i pochodzenie jezuitów przebywających w Galicji w chwili kasaty $1848 \mathrm{r}$. Uwagę zwraca jedyny wydany w $1848 \mathrm{r}$. drukiem katalog${ }^{24}$, ale najbardziej kompleksowy charakter ma rękopiśmienny spis jezuitów sporządzony w tym samym roku ${ }^{25}$.

W zbiorach CPAH-Lw. łatwo zauważyć bogaty zbiór planów różnych klasztorów, przede wszystkim katolickich. Kolekcja ta nie jest związana wyłącznie z Galicją, choć większość szkiców dotyczy właśnie jej terenu, a przede wszystkim obszaru Lwowa. Plany kościołów jezuickich, kolegiów, konwiktów i terenów

${ }^{20}$ L. Grzebień, Konwikt szlachecki we Lwowie w l. 1842-1848, [w:] Jezuicka ars educandi. Prace ofiarowane Księdzu Profesorowi Ludwikowi Piechnikowi SJ, red. M. Wolańczyk i S. Obirek SJ, Kraków 1995.

21 S. Cieślak, Działalność społeczno-kulturalna jezuitów galicyjskich $w$ stowarzyszeniach katolickich 1856-1914, Kraków 2013, s. 50.

22 Centralne Państwowe Archiwum Historyczne Ukrainy we Lwowie [dalej: CPAH-Lw.], fond [dalej: f.] 146, opis [dalej: op.] 7, nr 2671.

${ }^{23}$ Ibidem, op. 66, nr 2011-2013.

24 „Typis instituti staurupigiani”, CPAH-Lw., f. 146, op. 66, nr 2011.

${ }^{25}$ CPAH-Lw., f. 146, op. 7, nr 2671. W CPAH-Lw. znajdują się ponadto rękopiśmienne listy nazwisk członków zakonu z lat 1835, 1836 i 1855 r. (ibidem, nr 2010 i 2016). 
należących do zakonu powstawały w związku z kasatami, a następnie przystosowywaniem pojezuickiego majątku do nowych funkcji. Wyjątkiem jest kopia szkicu topograficznego z 1691 r., z pewnością przydatnego w czasach pierwszej kasaty, ponieważ prezentuje on szczegółowy obraz obszaru stopniowo zajmowanego przez jezuitów.

Kolekcja planów została rozmieszczona przez archiwistów przede wszystkim w dwóch zespołach. Pierwszym z nich jest fond nr 742, znany jako „Kolekcja map i planów”, obejmujący zbiór źródeł tego typu z lat 1775-1952. Początkowo były to plany wykonane w latach osiemdziesiątych XVIII w. w związku z porządkowaniem centralnej części miasta Lwowa, a po kasatach z przebudowywaniem klasztorów na szkoły, szpitale, wojskowe koszary, sądy i więzienia. Obecny inwentarz tego zespołu został wprawdzie udostępniony dopiero w 1984 r., ale u jego podstawy znajdują się plany uporządkowane już w 1787 r. Miało to związek z powstaniem Archiwum Miejskiego przy lwowskim Magistracie. Dopiero w 1937 r. kolekcja została przejęta przez Archiwum Akt Dawnych we Lwowie i to właśnie do jego zasobów wpływały plany i mapy powstałe w XIX w. Reorganizacji zbiorów, czyli inwentaryzacji i opracowywaniu na nowo zasobów archiwalnych, towarzyszyło wyłączanie planów z dotychczasowych zespołów i przesunięcie ich do fondu nr 742. Praca ta została wykonana dość starannie, choć do dzisiaj jeszcze można odnaleźć przeoczone egzemplarze w aktach kasacyjnych. Dokumenty związane z klasztorami znajdują się w dziale XI znanym jako „Obiekty pamiątkowe kultu i architektury”, w którym część 3 zawiera plany różnych klasztorów.

Drugim z zespołów stworzonych w celu uporządkowania kolekcji planów jest fond nr 726, czyli ,Zbiór planów szkół, cerkwi, szpitali, więzień oraz innych budynków państwowych i prywatnych na terenie Galicji”. Powstał on w Archiwum Państwowym we Lwowie. Rdzeniem tej kolekcji są plany powstałe w latach osiemdziesiątych XVIII w., również w związku z porządkowaniem centrum miasta oraz przebudową poklasztornych budynków. Z upływem lat zespół ten uzupełniono planami pochodzącymi z innych archiwów, natomiast opisano w $1918 \mathrm{r}$.

Wymienione wyżej fondy były już penetrowane przez autorów serii książek poświęconych kościołom i klasztorom rzymskokatolickim we Lwowie i w dawnym województwie ruskim ${ }^{26}$. Oryginalnych planów pochodzących z tych ważnych zespołów reprodukowanych jest w pracy niewiele, natomiast znalazło się tutaj miejsce dla planów kościoła i kolegium jezuickiego z lat 1632 i 1647, a także dla planu tych budynków pochodzącego z końca XVIII w. i dwóch planów z drugiej połowy XIX i początku XX w. Dostępny, bogaty materiał archiwalny zachęca zatem do podjęcia próby edycji tych źródeł. Jest to celowe tym bardziej, że poza sferą zainteresowania historyków sztuki pozostaje kilka pięk-

${ }^{26}$ Kościoly i klasztory Lwowa z okresu przedrozbiorowego, cz. 20(2), oprac. A. Betlej, M. Biernat, M. Kurzej, J.K. Ostrowski, Kraków 2012. 
nych i szczegółowych szkiców terenu folwarku jezuickiego zwanego potocznie „Ogrodem Jezuickim” lub „Wólką Jezuicką”. Znajdujący się tutaj obecnie park im. Iwana Franki (Park Kościuszki) jest uważany za najstarszy park miejski, a uwagę przyciąga dobrze przemyślane położenie tego dużego obszaru zieleni. $Z$ jego terenu na Krakowskim Przedmieściu otwiera się bowiem widok na dawny Sejm Galicyjski, czyli późniejszy Uniwersytet im. Jana Kazimierza. Wcześniej stała w tym miejscu jezuicka „villa”. Dzięki zachowanym źródłom wykorzystanym częściowo przez S. Załęskiego, można pokrótce opisać historię lwowskiej posiadłości jezuitów. Część obszaru istniejącego do końca XVIII w. folwarku jezuickiego została w 1602 r. kupiona od mieszczki Szolcowej, natomiast drugą jego część podarował zakonowi jej mąż, Stanisław Szolc ${ }^{27}$. Po kasacie zakonu „Wólka Jezuicka” pozostawała w zaniedbaniu aż do 1799 r., gdy rząd austriacki oddał ją w dzierżawę traktiernikowi miejskiemu Janowi Hechtowi za sumę 3410 złotych reńskich (złr.). W 1855 r. teren ten został wykupiony przez miasto, a istniejący tu park francuski został szybko przekształcony przez ogrodnika Bauera w kompleks utrzymany w duchu angielskim. Zachowane plany pokazują kolejne prace nad modyfikacją i upiększaniem tego wyeksponowanego miejsca.

Uzupełnieniem kolekcji planów są nieliczne szkice zamieszczone w innych zespołach archiwalnych. Jednym z nich jest „Zbiór akt dotyczących sprzedaży posiadłości królewskich i kościelnych”, czyli fond nr 453. Rdzeń tego zespołu powstał pod koniec XVIII w., ponieważ w tym czasie władze austriackie konfiskowały i sprzedawały dawne posiadłości królewskie oraz majątek klasztorów poddanych kasacie. Początkowo dokumenty te pozostawały w ręku Krajowej Dyrekcji Skarbu, a pod koniec XIX w. zostały przekazane Uniwersytetowi Lwowskiemu. W zbiorach Archiwum Państwowego znalazły się w 1919 r. Z lat 1792-1847 pochodzą przechowywane tu dokumenty dotyczące sprzedaży działek pojezuickich we Lwowie, a atrakcją tej kolekcji są znajdujące się w niej plany ${ }^{28}$.

Niezależnie od fondów i jednostek archiwalnych stworzonych w celu wyodrębnienia planów i map, można je z łatwością odnaleźć w aktach kasacyjnych. Są to w większości sprawozdania omawiające stan finansowy klasztorów w momencie ich likwidacji, a niekiedy także na pewien czas przed kasatą. Konfiskatę mienia klasztornego poprzedzało pojawienie się arcybiskupiego delegata i komisarza rządowego, którzy odczytywali zakonnikom breve, a następnie rekwirowali m.in. księgi rachunkowe i inwentarze dóbr ziemskich. Czynności te poprzedzały zasadniczy krok, jakim było spisanie inwentarza kościelnego, kolegiackiego i szkolnego, a odnotowany i oszacowany majątek (dochody z folwarków i one same, kapitały, zawartość aptek i gmachów itd.) stawał się własnością skarbu. Skrupu-

${ }^{27}$ S. Załęski, Jezuici w Polsce, t. 4, cz. 2, s. 453, przyp. 3.

${ }^{28}$ CPAH-Lw., F. 453, op. 1, nr 1190. 
latność nakazywała komisji interesować się także testamentami i starymi dokumentami fundacyjnymi, dlatego łatwo je można napotkać w aktach kasacyjnych.

Dokumenty kasacyjne zostały w większości umieszczone w fondzie nr 146, czyli „Namiestnictwie Galicyjskim”. Jak wiadomo, dekretem z 16 kwietnia 1854 r. miejsce gubernatorów galicyjskich zajęli namiestnicy. Do ich kompetencji należało m.in. sprawowanie zarządu administracyjnego i policyjnego. Podlegały im także sprawy wyznaniowe, oświata i szkoły. Nie dziwi zatem, że także w tym fondzie należy szukać źródeł związanych z jezuitami. Znajduje się tutaj między innymi dokumentacja powstała przed $1854 \mathrm{r}$. Zawiera ją głównie opis 48 „Namiestnictwa Galicyjskiego”. W tym samym zespole znajduje się również obszerny tekst z 1800 r. omawiający historię Funduszu Religijnego w Galicji Zachodniej ${ }^{29}$. Widomą oznaką istnienia dużej liczby takich dokumentów jest podzielenie ich w obrębie zespołu na szereg tomów. Przykładowo, 10 tomów mieści w sobie akta dotyczące jezuitów spoza Galicji z lat 1773-1795². Możliwość dokonania wglądu w akta jezuitów działających poza zaborem austriackim może potencjalnie ułatwić pogłębienie wiedzy na temat ich kontaktów z jezuitami galicyjskimi. Zespół nr 146 zawiera również osiemnastowieczny rejestr dokumentów poświadczających prawo własności do dóbr ziemskich kolegium jezuickiego w Samborze (Błażów i Wola Błażowska) ${ }^{31}$, oraz wyciąg z rejestru dokumentów kolegium jezuickiego w Stanisławowie z lat 1722-1766 ${ }^{32}$. Zakres chronologiczny oraz obfitość tego materiału skłaniają do wniosku, że dobrze odzwierciedla on kolejne etapy historii jezuitów po kasacie zakonu w $1773 \mathrm{r}$.

W zespole 134, czyli ,Zbiorze akt dotyczących majątków szlacheckich na terenie województw ruskiego, wołyńskiego, podolskiego i innych" znajduje się również wyciąg z rejestru dokumentów kolegium jezuickiego w Stanisławowie z lat 1722-1766 oraz z 1774 r. ${ }^{33}$ Dokumenty będące niegdyś własnością jezuitów stanisławowskich pochodzą z okresu przedkasatowego, a konkretnie z lat $1722-1766^{34}$. W CPAH-Lw. zgromadzono rejestry przywilejów, którymi szczyciły się placówki jezuickie, a także spisy ich dłużników. Jednym z przykładów mogą być ich księgi z lat 1794-17975 oraz papiery dokumentujące rozgraniczenia dóbr jezuickich, np. we wsiach Baczów i Podusielnia oraz królewszczyzn w Podgrodziu z lat 1628-17693.

${ }^{29}$ CPAH Lw., f. 146, op. 1, nr 232, s. 1-38.

${ }^{30}$ Ibidem, op. 84, nr 3543-3546 (t. 1-3 z 1. 1773-1775); ibidem, nr 3543-3546 (t. 4 z 1. 1773-1775); ibidem, nr 3547-3552 (t. 5-10 z 1. 1776-1795).

${ }^{31}$ Ibidem, nr 36, k. 1-2.

32 Ibidem, nr 146.

33 Ibidem, nr 46, k. 1-5.

${ }^{34}$ Ibidem, op. 1, nr 146,

${ }^{35}$ CPAH- Lw., f. 134, op. 2, nr 52, k. 1-52.

${ }^{36}$ Ibidem, nr 74, k. 1-59. 


\section{Kasata zakonu w 1773 r.}

Dokumenty związane z dokonaną w 1773 r. kasatą zakonu jezuitów zostały przez archiwistów lwowskich wyodrębnione. Kluczowe znaczenie miało dla jezuitów breve papieża Klemensa XIV, mocą którego kasacie miały podlegać Towarzystwa Jezusowe we wszystkich krajach. Papieskie breve kasacyjne zostało ogłoszone 50 jezuitom lwowskim 28 września 1773 r. przez biskupa sufragana Samuela Głowińskiego w ich własnym kolegium. Zanim wkroczyły komisje lustracyjne, na wieść o ogłoszeniu kasaty część majątku jezuickiego przechwycili dawni fundatorowie zakonu oraz ich sukcesorzy. Jak barwnie napisał Załęski:

[...] prostym najazdem zabierali krescencyę, stadninę i bydto, ryby ze stawów, najpiękniejsze drzewa wycięli w lesie, posunawszy kopce granice, pozajmowali grunta jezuickie, tak, że na wielu miejscach, gdy przybyli z początkiem listopada lustratorowie, znaleźli „Arabiam desertum". Nawet z kolegiów wynoszono sprzęty, naczynia kuchenne, z kościołów srebra i wota, drogie materye, dywany, stowem jako "res nullius" uważano to wszystko i rozdrapano ${ }^{37}$.

Warto zatem podkreślić, że zachowane inwentarze nie muszą być w pełni wiarygodne. Mogą także nie odzwierciedlać rzeczywistego stanu posiadania jezuitów w okresie przedkasatowym. Pieniądze pozyskane ze sprzedaży dóbr poklasztornych miały być przeznaczone głównie na cele szkolne, w tym także na seminaria duchowne. Komisarze rządowi spisali szczegółowy inwentarz sprzętów i sreber kościelnych znajdujących się w jezuickim kościele św. Piotra i Pawła we Lwowie i zarekwirowali wszystko, co stanowiło realną wartość. Kościół pojezuicki przeznaczono na świątynię garnizonową. Losy skonfiskowanych przedmiotów wykonanych z metali szlachetnych były różne. Częstą praktyką było przetapianie ich na potrzeby mennicy. Jak stwierdził J. Sygański, kosztowności zdobiące obraz św. Stanisława Kostki szybko przepadły. W 1786 r. srebrną sukienkę odesłano do mennicy w Wiedniu, a wota przetopiono, aby następnie wykonać monstran$\mathrm{cję}^{38}$. Według Załęskiego, ocalała tylko jedna srebrna i pozłacana monstrancja oraz kilka srebrnych kielichów. Srebrne wota i pozostały „sprzęt” kościelny utracono na zawsze ${ }^{39}$. Odszukanie w rozległym materiale źródłowym wykazów dóbr ruchomych będących przed kasatą własnością jezuitów jest możliwe pod warunkiem przeprowadzenia starannej kwerendy. W inwentarzach uwzględniano przede wszystkim informacje oceniane jako najbardziej pożyteczne z uwagi na finansowy cel kasat. Spisywano zatem obszerne rejestry przedstawiające dochodowość dóbr jezuickich przed i po dokonanej konfiskacie ${ }^{40}$.

${ }^{37}$ S. Załęski, Jezuici w Polsce, w skróceniu 5 tomów w jednym, z dwoma mapami, Kraków 1908, s. 246.

38 J. Sygański, Święty Stanisław Kostka..., s. 156.

${ }^{39}$ S. Załęski, Kościół oo. Jezuitów we Lwowie pod wezwaniem śś. Apostotów Piotra i Pawła, s. 19.

${ }^{40}$ CPAH-Lw., f. 146, op. 84, nr 3591-3596, t. 7-9. 
Jednym z najważniejszych zespołów mieszczących w sobie źródła powstałe w wyniku kasat jezuitów w Galicji i poza jej obrębem jest fond nr 146, noszący nazwę „Namiestnictwa Galicyjskiego”. To tutaj właśnie znajdują się w większości akta kasaty dokonanej na obszarze Galicji w 1773 r., a także akta kasaty przeprowadzonej poza Galicją ${ }^{41}$. Istotną częścią takich dokumentów były decyzje o sprzedaży dóbr jezuickich w Galicji z lat 1775-1778, a w konsekwencji również zarządzenia dotyczące przeprowadzanych licytacji ${ }^{42}$. W fondzie $\mathrm{nr} 146$ pogrupowano dokumentację finansową pochodzącą z lat 1756-1840, związaną ogólnie z jezuitami galicyjskimi ${ }^{43}$. W „Namiestnictwie Galicyjskim” można się także doszukać bardzo interesujących akt majątkowych odnoszących się do pojezuickich i podominikańskich dóbr w Tarnopolu z lat 1904-190844.

Informacje na temat stanu finansowego dóbr jezuickich są jednak rozrzucone w różnych fondach. Miejsce poczesne zajmują wprawdzie akta majątkowe jezuitów galicyjskich pochodzące z latach 1774-1782 zgromadzone w „Namiestnictwie Galicyjskim" "45, ale dwa tomy sprawozdania omawiającego stan finansowy dóbr jezuickich z 1774 r. znajdują się już w fondzie nr 187, czyli w „Państwowej Buchalterii Państwowej”"46. Organ o takiej właśnie nazwie powstał w 1773 r. i prowadził ewidencję dochodów i rozchodów krajowych państwa. Miał on zatem wiele wspólnego z dochodami i wydatkami z Funduszu Religijnego. Pochodzące z lat 1775-1778 trzytomowe akta charakteryzujące proces sprzedaży dóbr jezuickich w Galicji zamieszczono natomiast w „Namiestnictwie Galicyjskim” ${ }^{4}$. Można to częściowo wyjaśnić różnicą kompetencji obu organów, a w archiwum przyjęto zasadę układania dokumentów według kryterium struktury władz galicyjskich i struktury kancelarii austriackiej.

Zachowane dokumenty pozwalają lepiej naświetlić losy budynków pojezuickich. W 1782 r. kościół św. Piotra i Pawła znalazł się w posiadaniu kanoników kapituły lwowskiej. Pojezuicka świątynia stała się odtąd kościołem filialnym parafii katedralnej. Odbywały się w nim nabożeństwa dla młodzieży szkolnej i uniwersyteckiej ${ }^{48}$. Czasy te utrwaliła dokumentacja charakteryzująca stan finan-

${ }^{41}$ Ibidem, op. 1, nr 103, k. 1-102 oraz ibidem, op. 84, nr 3602-3618, t. 1-17; ibidem, nr 35433546 oraz ibidem, nr 3547-3552.

42 CPAH-Lw., f. 146, op. 84, nr 3599-3601, t. 1-3.

43 Ibidem, nr 3602-3618, t. 1-6.

44 Ibidem, op. 5a, nr 953a, k. 1-29.

45 CPAH-Lw., f. 146, op. 84, nr 3588-3593, t. 1-4.

46 Ibidem, f. 187, op. 1, nr 2-4.

47 CPAH-Lw., f. 146, op. 84, nr 3599-3601, t. 1-3.

48 Po II wojnie światowej kościół został zamknięty i zamieniony na magazyn książek i czasopism. Po ogłoszeniu niepodległości Ukrainy magazyn przejęła Biblioteka im. W. Stefanyka. W 2010 r. zapadła decyzja o otwarciu kościoła, zamienionego w unicką świątynię garnizonową. 27 maja 2013 r. miał miejsce w Parlamencie Europejskim wernisaż wystawy „Dawny kościół Jezuitów we Lwowie, międzynarodowa inicjatywa ratowania europejskiego dziedzictwa kultury 
sowy siedzib jezuickich w Galicji w latach 1777-1784, 1783-1795 i 1784-180849. Niemniej interesujące od losów jezuickiej świątyni we Lwowie są pokasatowe dzieje lwowskiego kolegium. Zostało ono założone w 1608 r., a począwszy od 1661 r. funkcjonowało jako Akademia Jezuicka. W 1758 r. August III Wettin podpisał dyplom potwierdzający przywilej Jana Kazimierza z roku 1661, którym nadano lwowskiej Akademii prawa takie, jakie posiadała Akademia Krakowska. Rok później papież Klemens XIII wydał bullę zatwierdzającą Akademię Lwowską i zarazem podnoszącą ją do godności uniwersytetu ${ }^{50}$.

Zapowiedzią niekorzystnej atmosfery wokół Akademii Lwowskiej było jednak nie potwierdzenie jej przywilejów przez Stanisława Augusta na sejmie koronacyjnym w 1764 r.. W 1774 r. jezuici opuścili Lwów, a rząd austriacki przekazał część ich majątku Galicyjskiemu Funduszowi Religijnemu. Pozostała część własności zakonu przeszła $\mathrm{w}$ ręce różnych organizacji gubernialnych. Budynek kolegium został przejęty przez trybunał cywilny (Sąd Krajowy) oraz Dyrekcję Skarbową. Akademię Lwowską przekształcono wówczas w szkołę średnią kształcącą swoich uczniów w zakresie filozofii i prawa ${ }^{51}$. Jeszcze po I wojnie światowej w budynku dawnego kolegium pracował Sąd Okręgowy. Obecnie cały budynek zajmuje szkoła średnia nr 62.

Cenne dokumenty mieści w sobie fond nr 453, gdzie przechowywane są księgi rejestrowe majątku pojezuickiego we Lwowie ${ }^{52}$. W tym samym zespole zamieszczono również dokumentację sprzedaży majątku jezuitów lwowskich Janowi Hechtowi (1792-1847) ${ }^{53}$, a także księgę wyceny majątków skasowanych klasztorów jezuickich pochodzącą z $1773 \mathrm{r}^{54}$ Istotne miejsce zajmują w tym materiale źródłowym dokumenty z lat 1773-1864, spisane właśnie w takim celu ${ }^{55}$. W zespole nr 453 znajduje się zbiorcza księga wyceny majątku skasowanych klasztorów jezuickich z lat $1777-1784^{56}$, z której pochodzą dane liczbowe znajdujące się w poniższej tabeli:

na Ukrainie”. Nad renowacją świątyni pracuje zespół specjalistów z Polski, Ukrainy i Rumunii. Konserwacji wymagają osiemnastowieczne freski wykonane przez sprowadzonych z Brna malarzy - Franciszka Eksteina i jego syna Sebastiana. Zachował się alabastrowy sarkofag arcybiskupa lwowskiego Mikołaja Wyżyckiego oraz hebanowy krucyfiks z 1616 r., wykonany prawdopodobnie przez Jana Pfistera.

${ }^{49}$ CPAH-Lw., f. 453, op. 1, nr 20; f. 146, op. 84, nr 3591-3596, t. 7-9.

5050

${ }^{51} \mathrm{Na}$ bazie dawnej Akademii powstały również Kolegium Medyczne (Collegium Medicum) i Kolegium Teologii Katolickiej dla młodzieży szlacheckiej (tzw. Akademia Stanowa).

${ }^{52}$ CPAH-Lw., f. 453, op. 1, nr 16, 17, 18, 19, 20, 21, s. 1-98.

${ }^{53}$ Ibidem, nr 1190, k. 1-69.

${ }^{54}$ Ibidem, $\mathrm{nr} 7$.

55 Ibidem, op. 1, nr 16.

${ }^{56}$ Ibidem, nr 17. 
Tabela 1

Wycena wartości części majątku (złp.) skasowanych dóbr jezuickich w Galicji z 1777 r.

\begin{tabular}{|c|c|c|c|}
\hline Lp. & Miejscowość & Kolegium & Dom misyjny \\
\hline 1. & Jarosław & 202000,00 & - \\
\hline 2. & Jordanów & - & 17400,00 \\
\hline 3. & Kraków & 148300,00 & - \\
\hline 4. & Krasnystaw & 19244,00 & - \\
\hline 5. & Krosno & 1000,00 & - \\
\hline 6. & Lwów & 12685,27 & - \\
\hline 7. & Nastazów & - & 3709,10 \\
\hline 8. & Przemyśl & 98600,00 & - \\
\hline 9. & Rożniatów & - & 6206,70 \\
\hline 10. & Sambor & 4500,00 & - \\
\hline 11. & Sandomierz & 64000,00 & - \\
\hline \multirow[t]{2}{*}{12.} & Stanisławów & 72534,13 & - \\
\hline & Razem & 421065,70 & 27315,80 \\
\hline
\end{tabular}

Dane ujęte w tabeli odzwierciedlają jednak zaledwie część majątku jezuitów galicyjskich w 1777 r. Komisja sporządzająca inwentarze oceniła jego łączną wartość na sumę 650979,27 1/2 złr. ${ }^{57}$ Czysty dochód powstawał po odliczeniu wydatków związanych z utrzymaniem budynków kolegium i kościoła, oraz służby domowej. $Z$ dochodu czystego utrzymywano jezuitów, dlatego w źródłach określano, ile osób może utrzymać kolegium i jaką sumę należy wydawać rocznie na jednego zakonnika. Jak zauważył autor książki poświęconej kolegium

${ }^{57}$ Ibidem, nr 19 i 20. 
w Jarosławiu, od drugiej połowy XVII w. - zważywszy na straty spowodowane wojnami połowy tego stulecia - coraz większą rolę odgrywały procenty od kapitału przynoszące zysk w gotówce ${ }^{58}$. Podane wyżej liczby można oczywiście spróbować zestawić z inwentarzami uwzględniającymi szersze ramy chronologiczne.

W oparciu o znane sobie źródła S. Załęski zgromadził informacje o wartości majątku jezuitów lwowskich i stanisławowskich Do przedstawionych przez niego danych można dołączyć ustalenia dotyczące kolegium w Rożniatowie. Uzupełnienie tych danych pozwoliłoby zweryfikować opinie starszej historiografii na temat rozmiaru majątku jezuitów w momencie kasaty, a także lepiej ocenić rozmiar jego spustoszenia przed wkroczeniem komisji lustracyjnych. Lwowskie kolegium oraz kościół św. Piotra i Pawła były przecież zaledwie częścią rozległego obszaru jezuickich nieruchomości. W zachowanych do dzisiaj inwentarzach odnoszących się do Lwowa wymieniono także drukarnię, aptekę, 11 folwarków, pięć jurydyk we Lwowie, grunta miejskie z kamienicami, ogród za miastem, bursę muzyków, obserwatorium astronomiczne i dwór zajezdny. Lwowscy jezuici posiadali także kolegium szlacheckie przy ulicy Ruskiej, a wartość ich konwiktu wyceniono w czasie kasaty na 72000 złp. ${ }^{59}$

Materiały źródłowe przechowywane w CPAH-L dotyczą także majątku jezuickiego położonego w innych miejscowościach Galicji, a zatem warto porównać ich zawartość ze źródłami wykorzystanymi już w dotychczasowych badaniach. W przypadku dóbr jezuickich w Stanisławowie odnotowano na przykład w $1770 \mathrm{r}$. wydatki - między innymi na administrację - w wysokości 3970 złp. Czysty dochód wynosił tu 4500 złp., a długi wyceniono na 24000 złp. ${ }^{60}$ Wskazywałoby to na trudną sytuację materialną jezuitów stanisławowskich. Nieco lepszą kondycją finansową odznaczali się natomiast jezuici w Rożniatowie. Czysty dochód wynosił tutaj wprawdzie tylko $1560 \mathrm{złp}$., ale w inwentarzach nie odnotowano żadnych długów. Majątek stacji misyjnej w Nastazowie oceniono w 1774 r. na 66680 zlp. $^{61}$

Dane finansowe ukazujące stan dóbr klasztornych w Galicji w latach 17771789 znajdują się również w fondzie nr 187, czyli w „Buchalterii Państwowej we Lwowie"62. Zamieszczono tutaj m.in. sporządzoną w 1777 r. listę dłużników skasowanych klasztorów w Galicji ${ }^{63}$, a także listę dłużników klasztoru jezuitów skasowanego w Zamościu, spisaną w tym samym roku ${ }^{64}$. Istotne dla badaczy mogą być także informacje o dobrach ziemskich należących do jezuitów w Białej, Krakowie, Krośnie, Kamieńcu Podolskim, Laszkowie, Łyczkowicach,

\footnotetext{
${ }^{58}$ K. Leń SJ, Jezuickie kolegium św. Jana w Jarostawiu 1573-1773, Kraków 2000, s. 79-80.

${ }^{59}$ Encyklopedia wiedzy o jezuitach..., s. 379.

${ }^{60}$ S. Załęski, Kolegium jezuickie w Stanisławowie. Szkic historyczny, Nowy Sącz 1896, s. 66.

${ }^{61}$ Encyklopedia wiedzy o jezuitach..., s. 452.

${ }^{62}$ CPAH-Lw., f. 187, op. 1, nr 14, k. 1-41.

${ }^{63}$ Ibidem, nr 15, k. 1-31.

${ }^{64}$ Ibidem, nr 16.
} 
Nastazowie (1777 r.) ${ }^{65}$, we Lwowie i Jarosławiu (1777 r.), a także w Jordanowie, Żywcu, Białej, Rożniatowie, Samborze, Stanisławowie, Przemyślu i Jarosławiu (lata 1777-1779) ${ }^{66}$. Z 1774 r. pochodzą zachowane w fondzie nr 187 sprawozdania o jezuickich dobrach przechowywane w dwóch tomach ${ }^{67}$. Znajdziemy tutaj także sprawozdanie finansowe odzwierciedlające stan majątku zakonu w $1788 \mathrm{r}^{68}$ $\mathrm{W}$ fondzie nr 187 znajduje się ponadto zbiór 13 dokumentów zawierających dane pochodzące z lat 1776-1780, odzwierciedlające stan majątku ruchomego pozostałego w kolegiach lwowskim i samborskim ${ }^{69}$. Uzupełnieniem dokumentacji związanej z jezuitami jest niewątpliwie zbiór akt dotyczących kolegium w Tarnopolu z lat $1820-1833^{70}$. W „Buchalterii Państwowej we Lwowie” zachowały się rozliczenia $\mathrm{z}$ dzierżawcami dóbr należących wcześniej do jezuitów, a także informacje podatkowe oraz korespondencja z gubernatorem Galicji. Częścią tego cennego zbioru archiwalnego są również sprawy majątkowe kolegium jezuickiego w Krośnie z 1782 r. ${ }^{71}$

W monarchii habsburskiej kasowano klasztory w dwóch etapach, zaczynając od zakonów kontemplacyjnych (1782-1783). W 1782 r. poddano sekularyzacji klasztory kartuzów, a 12 stycznia $1782 \mathrm{r}$. z kancelarii cesarskiej wyszedł dekret nakazujący kasatę wszystkich męskich i żeńskich zakonów nie zajmujących się edukacją, nauką i opieką nad chorymi. Skonfiskowane majątki klasztorne przeszły na własność Funduszu Religijnego, którego zadaniem było zakładanie szkół i szpitali. Sumy pozyskane z konfiskaty przeznaczono także na zakładanie nowych parafii. Drugi etap kasat przypadł na lata 1784-1787. Polityka kościelna Józefa II zakładała zarazem tolerancję dla innowierców i prawosławnych, co podkreślił edykt wydany w 1781 r. Był to tak zwany „Toleranz - Gestz”, w którym cesarz uczynił siebie najwyższą władzą w sprawach duchownych, o ile nie dotyczyły one dogmatów. Władca ingerował jednak między innymi w sposób odprawiania nabożeństw.

\section{Przywrócenie zakonu jezuitów w 1814 r.}

Historia zakonu jezuitów w zaborach austriackim i rosyjskim toczyła się do $1820 \mathrm{r}$. odmiennymi torami, mimo tego, że decyzja rozwiązania zakonu podjęta przez Klemensa XIV nie uwzględniała wyjątków. W Galicji majątek jezuicki poddano konfiskacie dwukrotnie - w 1773 i 1848 r., podczas gdy na ziemiach zaboru rosyjskiego dekretu kasacyjnego nie ogłoszono i jezuici w spokoju docze-

\footnotetext{
${ }^{65}$ Ibidem, nr 6-12, k. 1-17.

${ }^{66}$ Ibidem, nr 17; nr 18-23.

${ }^{67}$ Ibidem, nr 2-4.

${ }^{68}$ CPAH-Lw., f. 453, op. 1, nr 36, 1-17; ibidem, nr 37-41.

${ }^{69}$ Ibidem, f. 187, op. 1, nr 5, k. 1-13.

${ }^{70}$ Ibidem, f. 146, op. 66, nr 1673, k. 1-93.

${ }^{71}$ Ibidem, nr 43-76 i 47-48, t. 1-2, k. 1-35.
} 
kali tu formalnego restytuowania swego zakonu. W 1801 r. prowincja białoruska mogła świętować wznowienie zakonu w Rosji, a trzynaście lat później decyzją tą objęto jezuitów na całym świecie ${ }^{72}$.

O podjęciu tak istotnego dla zakonu kroku zadecydował w 1814 r. papież Pius VII. Zmieniony został jednak jego statut, a zakonników poddano rygorystycznej kontroli sprawowanej przez zwykłą hierarchię kościelną. Zachowane dokumenty dobrze oddają zmienność losów galicyjskich jezuitów na przestrzeni lat 1814-1848. Jezuici galicyjscy powrócili do Lwowa w 1820 r., a szesnaście lat później odzyskali swoją świątynię - kościół św. Piotra i Pawła ${ }^{73}$. W roku następnym otrzymali również potrynitarski kościół św. Mikołaja oraz znajdujący się przy nim konwikt szlachecki, który w latach 1839-1842 został zastąpiony nowym, dwupiętrowym budynkiem dzięki inicjatywie br. Fidelisa Stadlera ${ }^{74}$. W latach 1832-1836 świątynia pojezuicka znajdowała się jeszcze pod zarządem kapituły i nadal odbywały się w niej msze dla garnizonu. Uległo to zmianie, gdy 17 sierpnia 1836 r. gubernator - arcyksiążę Ferdynand d'Este - udzielił zgody na wznowienie działalności jezuitów na obszarze Galicji. Kilka dni później arcybiskup lwowski Franciszek Pisztek przekazał kościół i parafię w ręce reaktywowanego zakonu. Jezuici objęli wówczas w posiadanie parafię św. Mikołaja i konwikt szlachecki. Dużo zawdzięczali wstawiennictwu arcyksięcia Ferdynanda, dobrodzieja zakonu, który nie tylko ofiarował świątyni 400 złr., ale i wyjednał 1850 złp. z funduszu religijnego na odnowienie i rekonstrukcję dzwonnicy ${ }^{75}$. Było to konieczne, ponieważ w 1830 r., z rozkazu władz austriackich, rozebrano wieżę kościelną ${ }^{76}$. W 1836 r., dzięki przywilejowi cesarskiemu, jezuici otrzymali ponadto wolność nauczania według „Ratio studiorum”. Był to przełom bardzo istotny dla jezuitów w całej Galicji.

Przyszłość Towarzystwa Jezusowego okazała się jednak niełatwa. Zakonnicy z zaboru rosyjskiego przekonali się o tym już w 1820 r. $^{77}$ Dokonana wówczas kasata sprawiła, że ich losy splotły się z losami jezuitów w Galicji. Za panowania cara Aleksandra I najpierw wydalono zakonników z Petersburga, a gdy w $1820 \mathrm{r}$. zmarł generał zakonu Tadeusz Brzozowski ogłoszono, że majątek Towarzystwa Jezusowego podlega konfiskacie i jezuici muszą opuścić cesarstwo. Pozwolono tu pozostać pojedynczym zakonnikom, ale pod warunkiem przyjęcia statusu

${ }^{72}$ Encyklopedia wiedzy o jezuitach..., t. 1, s. 271.

73 Jezuicki kościół przekazano po kasacie pod opiekę księży profesorów Wydziału Teologicznego Uniwersytetu Lwowskiego, a później - od 1782 r. - należał on do kanoników kapituły lwowskiej.

${ }^{74}$ Encyklopedia wiedzy o jezuitach..., t. 1, s. 381.

75 J. Sygański, Święty Stanisław Kostka..., s. 33.

${ }^{76}$ Powodem niepokoju i podjętych działań prewencyjnych było zawalenie się cztery lata wcześniej wieży lwowskiego ratusza.

${ }^{77}$ Okres pomiędzy tym wydarzeniem a przejęciem przez rząd austriacki mienia jezuickiego w dobie Wiosny Ludów, opisał Władysław Chotkowski (Powrót i powtórne zniesienie jezuitów w Galicyi 1820-1848, Warszawa 1904). 
świeckich księży ${ }^{78}$. Większość z nich zdecydowała się jednak na wyjazd z Rosji, udając się m.in. do Galicji. Do Lwowa przybywali oni z Witebska, Mohylewa, Połocka, Użwałdu i Mścisławia. Państwo Habsburgów nie zawsze było dla nich miejscem docelowym ${ }^{79}$, ale arcybiskupowi lwowskiemu Andrzejowi Ankwiczowi i cesarzowi Franciszkowi II zależało na zatrzymaniu jezuitów w archidiecezji lwowskiej z uwagi na potrzeby parafian $^{80}$.

W granicach carskiej Rosji po pierwszym rozbiorze Rzeczpospolitej pozostawało 201 jezuitów - 97 ojców, 49 kleryków i 55 braci zakonnych - rozmieszczonych w 18 domach $^{81}$. Jak wynika z danych źródłowych, jezuici z zaboru rosyjskiego najliczniej przybywali do kolegium w Tarnopolu i kolegium w Nowym Sączu. Pracowały tam grupy liczące po 49 zakonników. Nieliczni przybysze osiedli w małych domach misyjnych w Milatynie, Staniątkach i Pieniakach tworząc tam trzon jezuickiej społeczności. W rezydencji łańcuckiej stanowili oni większość.

Obecność przybyszów z zaboru rosyjskiego w ośrodkach jezuickich Galicji poświadczają źródła powstałe w efekcie kasaty w 1848 r. W tym czasie jezuici posiadali cztery kolegia: w Tarnopolu, Starej Wsi, Nowym Sączu i Lwowie. Istniało także 5 domów misyjnych: w Łańcucie, Lwowie, Milatynie, Pieniakach i Staniątkach. Skład osobowy tych właśnie ośrodków dokumentują źródła powstałe w czasie kasaty 1848 r. Według Władysława Chotkowskiego, jedynie we Lwowie jezuici musieli opuścić swoją rezydencję, a dzięki protekcji hr. Agenora Gołuchowskiego pozostało ich w Nowym Sączu, Starej Wsi i Tarnopolu po kilku lub kilkunastu. W 1849 r. w Tarnopolu pozostał superior Jan Zranicki, a także 7 ojców, 2 scholastyków i 8 braci $^{82}$. W Starej Wsi nadal przebywał superior Wincenty Laszkiewicz, 5 ojców i 2 braci, a w Nowym Sączu superior Józef Podobied, 2 ojców i 5 braci ${ }^{83}$.

W lwowskich dokumentach związanych z kasatą wyliczono w 1848 r. z imienia i nazwiska członków zakonu, osobno w konwikcie lwowskim, kolegium w Tarnopolu, Nowym Sączu i Starej Wsi, rezydencji w Łańcucie oraz w domach misyjnych we Lwowie, Milatynie, Pieniakach oraz Staniątkach. Dokument ten został sporządzony dość starannie, w języku niemieckim. W świetle tego spisu

${ }^{78}$ Ibidem, s. 13.

79 Taką rolę pełniły: Rzym, Francja, Hiszpania, Anglia, Irlandia i Grecja.

${ }^{80}$ Cesarz pozwolił osiedlić się w swoim cesarstwie 50 zakonnikom, ale liczba ta była powiększana. W 1821 r. prezydent gubernialny hrabia Taffe oznajmił, że prowincjał jezuitów Stanisław Świętochowski wysłał do guberni imienny wykaz 50 jezuitów. Zastrzegł on, że prosi o pozwolenie na dołączenie do niego kolejnych nazwisk, co najprawdopodobniej dotyczyło nowych członków zakonu z zagranicy (S. Załęski, Jezuici w Polsce, w skróceniu pięć tomów w jednym, Kraków 1908, s. $83-84,274)$.

${ }^{81}$ A.P. Bieś SJ, Periodyzacja obecności Towarzystwa Jezusowego na ziemiach polskich. Struktury organizacyjne oraz oświatowo-edukacyjne i pastoralne formy aktywności, cz. 1, „Artykuły i rozprawy SPI" 2014, nr 17, s. 77.

${ }_{82}$ W. Chotkowski, Powrót i powtórne zniesienie jezuitów w Galicyi..., s. 128, przyp. 4.

${ }^{83}$ Ibidem, 
zakonników było łącznie 187 , a nie 179 , jak oszacował to Stanisław Załęski ${ }^{84}$. W tej liczbie przybyszów z Białorusi było 41 (ok. 22\%). W 1853 r. doliczono się ich już $123^{85}$

W momencie sporządzania spisów w konwikcie lwowskim odnotowano obecność jedynie 30 osób, choć w 1845 r. było tu 45 konwiktorów, a w krytycznym $1848 \mathrm{r}$. ich liczba dochodziła już do $52^{86}$. W łańcuckim domu misyjnym było w 1848 r. 7 osób, jednakże opuściły one później Łańcut, z wyjątkiem kapelana dworskiego Piotra Szychowskiego ${ }^{87}$. W domu misyjnym w Milatynie przebywało przed tą datą 4-6 zakonników, a w chwili rejestrowania ich w 1848 r. zauważono obecność 7. Po kasacie pozostał na miejscu jedynie Wincenty Perkowski ${ }^{88}$. W Pieniakach przebywało z reguły 2 księży i 1 brat zakonny ${ }^{89}$.

W zachowanym w dokumentach kasacyjnych w wykazie członków konwiktu lwowskiego nie występuje Jan Chrzciciel Frazelin, choć był on związany z tym miejscem od $1842 \mathrm{r}$. Nie ma go także w wykazie dotyczącym kolegium tarnopolskiego, choć pracował tu od 1839 r. ${ }^{90}$ Wadą prezentowanego tu spisu jest niekiedy niedostateczna staranność - m.in. mylnie odnotowano imię Karola Benischa (Alois). W kilku przypadkach nie odnotowano imion w ogóle. W wykazie tym zapisywano często nazwy rodzinnych miejscowości braci zakonnych, ale w przypadku przybyszów z Białorusi nie uwzględniano takich informacji.

Tabela 2

Spis jezuitów w świetle dokumentacji kasacyjnej z 1848 r.

\begin{tabular}{|c|l|l|l|}
\hline L.p. & \multicolumn{1}{|c|}{ Nazwisko i imię } & \multicolumn{1}{|c|}{ Miejsce pochodzenia } & \multicolumn{1}{c|}{$\begin{array}{c}\text { Miejsce pobytu } \\
\text { w Galicji }\end{array}$} \\
\hline 1. & Arciszewski Bazyli & Białoruś & dom misyjny we Lwowie \\
\hline 2. & Arnold Otton & Sauersdorf (?) & kolegium w Tarnopolu \\
\hline 3. & Badźko Mikołaj & Białoruś & kolegium w Tarnopolu \\
\hline 4. & Benisch Karol (Alois) & Czechy & kolegiumw Nowym Sączu \\
\hline
\end{tabular}

84 Ibidem, s. 286.

85 Ibidem.

86 Encyklopedia wiedzy o jezuitach..., t. 1, s. 381.

87 Ibidem, s. 384.

88 Ibidem, s. 424.

89 Ibidem, s. 505.

90 S. Cieślak, Działalność społeczno-kulturalna jezuitów galicyjskich $w$ stowarzyszeniach katolickich 1856-1914, Kraków 2013, s. 50. 
Spuścizna pojezuicka w zasobach...

\begin{tabular}{|c|c|c|c|}
\hline L.p. & Nazwisko i imię & Miejsce pochodzenia & $\begin{array}{l}\text { Miejsce pobytu } \\
\text { w Galicji }\end{array}$ \\
\hline 5. & Benisch Paweł & Ehrenberg (Morawy) & $\begin{array}{l}\text { konwikt św. Mikołaja } \\
\text { we Lwowie }\end{array}$ \\
\hline 6. & Biehl Johann & $\begin{array}{l}\text { Frauenreith/Svobodka } \\
\text { (Czechy) }\end{array}$ & kolegium w Tarnopolu \\
\hline 7. & Błażeg Jan & Robousy (Czechy) & kolegium w Tarnopolu \\
\hline 8. & Brobeil Paul & Brünn (Brno) (Morawy) & kolegium w Tarnopolu \\
\hline 9. & Brown Józef & Petersburg (Rosja) & $\begin{array}{l}\text { konwikt św. Mikołaja } \\
\text { we Lwowie }\end{array}$ \\
\hline 10. & Butkiewicz Alojzy & Białoruś & dom misyjny w Pieniakach \\
\hline 11. & Candon (?) & Wels (północna Austria) & dom misyjny we Lwowie \\
\hline 12. & Chmielewski Andrzej & Białoruś & kolegium w Nowym Sączu \\
\hline 13. & Chmielewski Ignacy & Białoruś & dom misyjny w Milatynie \\
\hline 14. & Chmielewski Tadeusz & Białoruś & kolegium w Tarnopolu \\
\hline 15 . & Ciechanowiecki Paweł & Białoruś & kolegium w Nowym Sączu \\
\hline 16. & Csapkai Augustyn & Preszów (Węgry/Słowacja) & kolegium w Nowym Sączu \\
\hline 17. & Cych Józef & Białoruś & kolegium w Nowym Sączu \\
\hline 18. & Czyhir Mateusz & Białoruś & $\begin{array}{l}\text { konwikt św. Mikołaja } \\
\text { we Lwowie }\end{array}$ \\
\hline 19. & Dengel Christian & Reutte (Tyrol) & $\begin{array}{l}\text { konwikt św. Mikołaja } \\
\text { we Lwowie }\end{array}$ \\
\hline 20. & Drozdowicz Tomasz & Białoruś & kolegium w Nowym Sączu \\
\hline 21. & Figna Johann & Cieszyn (Śląsk) & dom misyjny w Milatynie \\
\hline 22. & Galicz Jan & Białoruś & $\begin{array}{l}\text { konwikt św. Mikołaja } \\
\text { we Lwowie }\end{array}$ \\
\hline 23. & Goldschalt Adam & Morawy & kolegium w Tarnopolu \\
\hline 24. & Graff? & Lotaryngia & kolegium w Nowym Sączu \\
\hline
\end{tabular}


Tabela 2 cd.

\begin{tabular}{|c|c|c|c|}
\hline L.p. & Nazwisko i imię & Miejsce pochodzenia & $\begin{array}{l}\text { Miejsce pobytu } \\
\text { w Galicji }\end{array}$ \\
\hline 25. & Greiner (?) & $?$ & kolegium w Tarnopolu \\
\hline 26. & Grocholski Antoni & Białoruś & kolegium w Nowym Sączu \\
\hline 27. & Guillemaint Johann & Belgia & kolegium w Tarnopolu \\
\hline 28. & Haan Joseph & Belgia & kolegium w Tarnopolu \\
\hline 29. & Habenicht Franz & Seifersdorf (Czechy) & kolegium w Tarnopolu \\
\hline 30. & Harder Michael & Vőls (Tyrol) & dom misyjny we Lwowie \\
\hline 31. & Haslinger Alois & Linz (Sustria) & kolegium w Nowym Sączu \\
\hline 32. & Hawerdlik Jan & Př́bram (Czechy) & kolegium w Starej Wsi \\
\hline 33. & Hawryłowicz Piotr & Białoruś & rezydencja w Łańcucie \\
\hline 34. & Haza-Radlitz Maksymilian & Wiedeń (Austria) & kolegium w Starej Wsi \\
\hline 35. & Heller Ignaz & Lotaryngia & kolegium w Nowym Sączu \\
\hline 36. & Hinteroecker Johan & Spitz & $\begin{array}{l}\text { konwikt św. Mikołaja } \\
\text { we Lwowie }\end{array}$ \\
\hline 37. & Hildebrand (?) & $?$ & kolegium w Tarnopolu \\
\hline 38. & Hiwner Martin & Sauersdorf (?) & kolegium w Tarnopolu \\
\hline 39. & Horżak Oldrzich & Praga & kolegium w Tarnopolu \\
\hline 40. & Ilg Habczan & $?$ & kolegium w Tarnopolu \\
\hline 41. & Iten Franz & Spitz (Dolna Austria?) & dom misyjny we Lwowie \\
\hline 42. & Joller Franz & Toblach (Tyrol) & kolegium w Tarnopolu \\
\hline 43. & Jung Edmund & Nauders (Tyrol) & kolegium w Tarnopolu \\
\hline 44. & Kałłucha Teodozy & Białoruś & dom misyjny w Milatynie \\
\hline 45. & Kautny Łazarz (Łukasz) & Ołomuniec (Morawy) & kolegium w Tarnopolu \\
\hline
\end{tabular}


Spuścizna pojezuicka w zasobach...

\begin{tabular}{|c|c|c|c|}
\hline L.p. & Nazwisko i imię & Miejsce pochodzenia & $\begin{array}{l}\text { Miejsce pobytu } \\
\text { w Galicji }\end{array}$ \\
\hline 46. & Kawecki Michał & Białoruś & dom misyjny w Pieniakach \\
\hline 47. & Kiejnowski Franciszek & Podolina (Białoruś) & $\begin{array}{l}\text { konwikt św. Mikołaja } \\
\text { we Lwowie }\end{array}$ \\
\hline 48. & Kiejnowski Władysław & Podolina (Białoruś) & rezydencja w Łańcucie \\
\hline 49. & Kłosowski Mateusz & Białoruś & kolegium w Nowym Sączu \\
\hline 50 & Korsak Franciszek & Białoruś & kolegium w Starej Wsi \\
\hline 51. & Koruna Paul & Velké Pavlovice (Morawy) & kolegium w Nowym Sączu \\
\hline 52. & Kułak Jerzy & Białoruś & kolegium w Starej Wsi \\
\hline 53. & Kutschera Anton & Cieszyn (Śląsk) & kolegium w Starej Wsi \\
\hline 54. & Ledergei Zachariasz & $?$ & rezydencja w Łańcucie \\
\hline 55. & Lenz Anton & Rojan (Czechy) & $\begin{array}{l}\text { konwikt św. Mikołaja } \\
\text { we Lwowie }\end{array}$ \\
\hline 56. & Lipiński Augustyn & Frysztad (Śląsk Cieszyński) & kolegium w Nowym Sączu \\
\hline 57. & Lőchner Florian & Újezd/Augezd (Morawy) & kolegium w Nowym Sączu \\
\hline 58. & Łaszkiewicz Wincenty & Białoruś & kolegium w Starej Wsi \\
\hline 59. & Markijanowicz Jan & Białoruś & kolegium w Tarnopolu \\
\hline 60. & Markijanowicz Rafał & Białoruś & kolegium w Nowym Sączu \\
\hline 61. & Markiewicz Augustyn & Białoruś & rezydencja w Łańcucie \\
\hline 62. & Materna Józef & Żiżelice (Czechy) & kolegium w Tarnopolu \\
\hline 63. & Matter Johann & Cieszyn (Śląsk) & kolegium w Tarnopolu \\
\hline 64. & Meyer Ihnafor & Linz (Austria) & kolegium w Nowym Sączu \\
\hline 65. & Mätzler Johann & $\begin{array}{l}\text { Andelsbuch/Vorarlberg } \\
\text { (Austria) }\end{array}$ & kolegium w Tarnopolu \\
\hline 66. & Michałowski Adam & Białoruś & kolegium w Nowym Sączu \\
\hline
\end{tabular}


Tabela 2 cd.

\begin{tabular}{|c|c|c|c|}
\hline L.p. & Nazwisko i imię & Miejsce pochodzenia & $\begin{array}{l}\text { Miejsce pobytu } \\
\text { w Galicji }\end{array}$ \\
\hline 67. & Molinari Matteo & Mediolan (Włochy) & kolegium w Starej Wsi \\
\hline 68. & Morgenbesser Franz & $\begin{array}{l}\text { Podoliniec } \\
\text { (Węgry/Słowacja) }\end{array}$ & kolegium w Nowym Sączu \\
\hline 69. & Mrniak Franciszek & Rozdziałowice (Czechy) & $\begin{array}{l}\text { konwikt św. Mikołaja } \\
\text { we Lwowie }\end{array}$ \\
\hline 70. & Nemeczek Johan & Fürstenthal (Bukowina) & $\begin{array}{l}\text { konwikt św. Mikołaja } \\
\text { we Lwowie }\end{array}$ \\
\hline 71. & Nikolka Stefan & Rajec (Węgry/Słowacja) & $\begin{array}{l}\text { konwikt św. Mikołaja } \\
\text { we Lwowie }\end{array}$ \\
\hline 72. & Nizard Maurycy & Smaukmnich (?) & $\begin{array}{l}\text { konwikt św. Mikołaja } \\
\text { we Lwowie }\end{array}$ \\
\hline 73. & Oehler Johann & $\begin{array}{l}\text { Bolzano/Bozen } \\
\text { (południowy Tyrol) }\end{array}$ & kolegium w Nowym Sączu \\
\hline 74. & Ottiger Ignatz & Toblach (Tyrol) & kolegium w Tarnopolu \\
\hline 75. & Pawlik Johann & Węgry & kolegium w Nowym Sączu \\
\hline 76. & Perkowski Wincenty & Białoruś & dom misyjny w Milatynie \\
\hline 77. & Peterek Andrzej & $\begin{array}{l}\text { Kocurowice } \\
\text { (Śląsk Cieszyński) }\end{array}$ & kolegium w Nowym Sączu \\
\hline 78. & Piotrowski Tomasz & Białoruś & kolegium w Nowym Sączu \\
\hline 79. & Pitschmann Johann & Seisenberg (Słowenia) & kolegium w Tarnopolu \\
\hline 80. & Podobied Józef & Białoruś & kolegium w Nowym Sączu \\
\hline 81. & Proniewski Antoni & Białoruś & kolegium w Nowym Sączu \\
\hline 82. & Puszet Franciszek & Lipiny (?) & kolegium w Starej Wsi \\
\hline 83. & Rausch (?) & Klagenfurt (Karyntia) & kolegium w Tarnopolu \\
\hline 84. & Redl Edmund & Wiedeń (Austria) & kolegium w Nowym Sączu \\
\hline 85. & Reutt Kazimierz & Białoruś & dom misyjny w Milatynie \\
\hline 86. & Richardot Infidam (?) & (?) & kolegium w Tarnopolu \\
\hline
\end{tabular}


Spuścizna pojezuicka w zasobach...

\begin{tabular}{|c|c|c|c|}
\hline L.p. & Nazwisko i imię & Miejsce pochodzenia & $\begin{array}{l}\text { Miejsce pobytu } \\
\text { w Galicji }\end{array}$ \\
\hline 87. & Różanka Stanisław & Białoruś & dom misyjny w Milatynie \\
\hline 88. & Rufs Ferdinand & Morawy & kolegium w Starej Wsi \\
\hline 89. & Ruhs Łukasz & Morawy & kolegium w Starej Wsi \\
\hline 90. & Rupp Martin & $\begin{array}{l}\text { Schluderns } \\
\text { (Tyrol południowy) }\end{array}$ & kolegium w Tarnopolu \\
\hline 91. & Sacher Józef & Punkva (Czechy) & kolegium w Starej Wsi \\
\hline 92. & Sadowski Wincenty & Białoruś & kolegium w Tarnopolu \\
\hline 93. & Schicketanz Friedrich & Niemes (Czechy) & kolegium w Nowym Sączu \\
\hline 94. & Schmidt Johann & Hradisch (Morawy) & kolegium w Starej Wsi \\
\hline 95. & Schőn Joseph & $\begin{array}{l}\text { Engelsberg } \\
\text { (Śląsk Cieszyński) }\end{array}$ & kolegium w Nowym Sączu \\
\hline 96. & Schulak Franz & Nischitz (Morawy) & kolegium w Nowym Sączu \\
\hline 97. & Sedlak Jan & Jawornica (Czechy) & $\begin{array}{l}\text { konwikt św. Mikołaja } \\
\text { we Lwowie }\end{array}$ \\
\hline 98. & Siedmiogrodzki Józef & Białoruś & $\begin{array}{l}\text { konwikt św. Mikołaja } \\
\text { we Lwowie }\end{array}$ \\
\hline 99. & Siwocha Augustyn & Białoruś & kolegium w Tarnopolu \\
\hline 100. & Skrocki Ignacy & Białoruś & kolegium w Starej Wsi \\
\hline 101. & Skulina Józef & Pitrau (Śląsk Cieszyński) & kolegium w Nowym Sączu \\
\hline 102. & Snarski Paweł & Białoruś & dom misyjny w Staniątkach \\
\hline 103. & Spärl Józef & Fürstenthal (?) & kolegium w Starej Wsi \\
\hline 104. & Staré Johan & Hrastje (Kraina/Słowenia) & $\begin{array}{l}\text { konwikt św. Mikołaja } \\
\text { we Lwowie }\end{array}$ \\
\hline 105. & Stiebel Kacper & Laguna & kolegium w Starej Wsi \\
\hline 106. & Suszczewski Antoni & Białoruś & kolegium w Nowym Sączu \\
\hline 107. & Swaracki Mateusz & Białoruś & kolegium w Tarnopolu \\
\hline
\end{tabular}


Tabela 2 cd.

\begin{tabular}{|c|c|c|c|}
\hline L.p. & Nazwisko i imię & Miejsce pochodzenia & $\begin{array}{l}\text { Miejsce pobytu } \\
\text { w Galicji }\end{array}$ \\
\hline 108. & Szychowski Piotr & Białoruś & rezydencja w Łańcucie \\
\hline 109. & Śliwowski Michał & Krieg (Węgry/Słowacja) & kolegium w Tarnopolu \\
\hline 110. & Tock Anton & Lewocza (Węgry/Słowacja) & kolegium w Tarnopolu \\
\hline 111. & Tomanek Wincenty & Tupesy (Morawy Południowe) & kolegium w Starej Wsi \\
\hline 112. & Tomaszewicz Michał & Białoruś & dom misyjny w Milatynie \\
\hline 113. & Toms Paul & Linz (Austria) & kolegium w Nowym Sączu \\
\hline 114. & Walużynicz Teodor & Białoruś & dom misyjny w Staniątkach \\
\hline 115. & Wawretschka Józef & Ostrów (Śląsk) & dom misyjny w Pieniakach \\
\hline 116. & Weber Józef & Opawa (Śląsk) & kolegium w Nowym Sączu \\
\hline 117. & Weiss Adalbert & Wiedeń (Austria) & kolegium w Nowym Sączu \\
\hline 118. & Wiertler Johann & Toblach (Tyrol) & kolegium w Tarnopolu \\
\hline 119. & Windprecht Alois & Laguna & kolegium w Tarnopolu \\
\hline 120. & Woglechowski Józef & Czechy & kolegium w Nowym Sączu \\
\hline 121. & Zaleski Józafat & Białoruś & kolegium w Tarnopolu \\
\hline 122. & Załęski Stefan & Białoruś & rezydencja w Łańcucie \\
\hline 123. & Zranicki Józef & Białoruś & kolegium w Tarnopolu \\
\hline
\end{tabular}

Dzięki nowo przybyłym jezuitom można było uzupełnić braki kadrowe w duszpasterstwie parafialnym, ale między oczekiwaniami zakonu a celami episkopatu istniały znaczące różnice. Biskupom zależało na poddaniu go własnej, pełnej jurysdykcji, co wynikałoby z ustawodawstwa józefińskiego. W tej sytuacji jezuici powołali się na przywilej egzempcji, czyli wyjęcia spod władzy miejscowego ordynariusza ${ }^{91}$. W efekcie udało im się wywalczyć otwarcie nowicjatu w budynkach klasztoru popaulińskiego w Starej Wsi, a następnie przystą-

${ }^{91}$ A.P. Bieś SJ, Jan Badeni (1858-1899). U początków ruchu społecznego katolików w Galicji, Warszawa 1999, s. 68-69. 
pili do zmagań o program nauczania, ponieważ władze austriackie domagały się kształcenia przyszłych kapłanów w duchu programu rządowego. Walka jezuitów o zatwierdzenie „studium domesticum” teologii zakończyła się powodzeniem, ale pod warunkiem korzystania $\mathrm{z}$ podręczników zatwierdzonych przez rząd i pozostawania pod nadzorem urzędników państwowych oraz konsystorza ${ }^{92}$.

\section{Delegalizacja zakonu w latach $\mathbf{1 8 4 8}-\mathbf{1 8 5 2}$}

Okres ten jest dość dobrze udokumentowany w zbiorach CPAH-Lw. Kolejnym przełomem w życiu galicyjskich jezuitów okazał się okres powstania $1846 \mathrm{r}$., a później Wiosna Ludów. W 1846 r. represjom poddano również zaangażowane w ruch narodowy duchowieństwo. Ponad 100 księży zostało wówczas aresztowanych za udział $\mathrm{w}$ przygotowaniach do powstania lub uczestniczenie $\mathrm{w}$ nim, a wielu z nich utraciło swoje probostwa ${ }^{93}$. Było to przyczyną początkowego nieangażowania się duchownych w przygotowania do galicyjskiej Wiosny Ludów. $\mathrm{Z}$ czasem jednak duchowieństwo parafialne włączyło się do walki, nie zaprzestając swojej działalności także po rozwiązaniu Komitetu Narodowego. W Centralnej Radzie Narodowej działało 21 księży i 2 biskupów, a księża głosili z ambon hasła niepodległościowe, potrzebę likwidacji pańszczyzny, nadania ziemi chłopom, a także amnestii dla więźniów politycznych. W tym czasie konwikt szlachecki we Lwowie opowiedział się za samorządnością Galicji i stworzył Gwardię Narodową. Został w 1848 r. zamknięty, kiedy wydano decyzję o kolejnej kasacie.

W 1848 r. rząd austriacki zabronił jezuitom działalności w Galicji. Akta kasacyjne zakonu jezuitów z lat 1847-1848 zachowały się w „Namiestnictwie Galicyjskim"94. Znajduje się tutaj m.in. rozporządzenie Kancelarii Dworskiej o kasacie jezuitów i kongregacji redemptorystów datowane na rok $1848^{95}$. $Z$ tego samego czasu pochodzi sprawozdanie Dyrekcji Policji we Lwowie, w którym zamieszczona została informacja o poparciu przez jezuitów powstania $1848 \mathrm{r} .{ }^{96}$ Jezuici lwowscy musieli opuścić kościół św. Piotra i Pawła, a zarząd nad nim ponownie przejęła Kapituła. Z tego burzliwego okresu zachowały się również dokumenty związane z jezuitami w Stanisławowie. Kościół jezuicki w tym mieście został przekształcony w 1849 r. w grecko-katolicką cerkiew parafialną, a potem stał się katedrą grecko-katolicką nowej diecezji stanisławowskiej ${ }^{97}$.

Osobną kwestią omawianą w dokumentach jest sprawa przyszłości jezuitów po kasatach, a dokładniej zapewnienia im podstawowych środków utrzymania.

\footnotetext{
${ }^{92}$ Ibidem, s. 74 .

${ }_{93}$ M. Stolarczyk, Udziat duchowieństwa rzymskokatolickiego w galicyjskiej Wiośnie Ludów. Próba charakterystyki, [w:] Rok 1848. Wiosna Ludów w Galicji. Zbiór studiów, red. W. Wic, s. 60.

${ }^{94}$ CPAH-Lw., f. 146, op. 7, nr 2671, k. 1-62.

${ }^{95}$ Ibidem, op. 84, nr 2819, k. 1-3.

${ }^{96}$ Ibidem, op. 7, nr 2818, k. 1-24.

${ }^{97}$ Ibidem, nr 2924, k. 1-4.
} 
Po kasacie zakonu przez papieża, nauczaniem zajmowali się tylko do 1 listopada 1784 r., ponieważ Józef II wprowadził odmienny od jezuickiego system kształcenia i tym samym pojawili się nauczyciele świeccy. Problem ten można bliżej naświetlić wykorzystując m.in. korespondencję i inne dokumenty z lat 17871810, w których poruszono kwestię mianowania jezuitów koadiutorami proboszczów w Galicji ${ }^{98}$. Dokumenty z okresu kolejnej delegalizacji zakonu, czyli z lat 1847-1849, potwierdzają podejmowanie prób częściowego zabezpieczenia materialnego starych księży oraz zapewnienia zakwaterowania misjonarzom ${ }^{99}$. Dokładniejsze badania mogłyby odpowiedzieć na pytanie, czy kroki te można uznać za wystarczające.

\section{Po abolicji 1853 roku}

Po 1849 r. zarysowywała się powoli odwilż w stosunkach między jezuitami a rządem. W 1850 r. podpisane zostały dokumenty, w których znajduje się informacja o udzieleniu zakonowi pozwolenia na celebrowanie liturgii ${ }^{100}$. Był to jeden z sygnałów zbliżającej się abolicji.

Pomimo burzliwych wydarzeń doby Wiosny Ludów i kolejnej konfiskaty jezuickiego majątku zakonnicy powrócili do Lwowa już w 1853 r. Klucze do kościoła św. Piotra i Pawła wręczono im 15 czerwca tego samego roku. $Z$ poprzedniego okresu utrzymała się tradycja odprawiania w nim mszy dla żołnierzy ${ }^{101}$. Inaczej nieco wyglądała natomiast sytuacja jezuitów stanisławowskich. Ich rezydencję przekazano w 1869 r. na potrzeby gimnazjum oraz poczty, co ilustruje korespondencja zachowana w fondzie nr 160 zwanym „Galicyjską Krajową Dyrekcją Skarbu we Lwowie" ${ }^{102}$. Organ ten utworzono w 1850 r., a do jego zadań należało m.in. dokonywanie kontroli skarbowej nad zarządem dóbr państwowych, kopalniami soli etc. Galicyjska Krajowa Dyrekcja Skarbu we Lwowie nadzorowała również proces ściągania podatków. W papierach pozostałych po jej działalności znajdują się zatem akty sprzedaży i dzierżawy gruntów należących do Funduszu Religijnego.

$$
* * *
$$

Po analizie wyników kwerendy w CPAH-Lw. nasuwa się wniosek, że czasy kolejnych kasat oraz abolicji zostały obficie udokumentowane. Niemal wszystkie zachowane plany pochodzą z XIX w., co dowodzi intensywnej w tym stuleciu pracy nad przekształcaniem budynków i terenów pojezuickich po ich skonfisko-

\footnotetext{
${ }^{98}$ Ibidem, op. 50, nr 1492.

${ }^{99}$ Ibidem, op. 7, $\mathrm{nr} 2671$.

100 Ibidem, nr 3017, k. 1-16.

${ }^{101}$ Dopiero w 1936 r. rada miejska przekazała jezuitom były kościół klarysek.

${ }^{102}$ CPAH-Lw., f. 160, op. 5, nr 2429, k. 1-5.
} 
waniu. Zachowane akta kasatowe, mimo zauważalnych w nich niedociągnięć, są obecnie cennym zbiorem odzwierciedlającym stan materialny zakonu, jego skład osobowy, a także postawy społeczne oraz polityczne wyrażane w okresach trudnych dla zaborów austriackiego i rosyjskiego.

\section{BIBLIOGRAFIA}

\section{Źródła rękopiśmienne:}

Centralne Państwowe Archiwum Historyczne we Lwowie

Fond 134, opis 1, nr 36, nr 146.

Fond 134, opis 2, nr 52, nr 74, nr 46.

Fond 146, opis 1, nr 103, nr 232.

Fond 146, opis 5a, nr 953a.

Fond 146, opis 7, nr 2010, 2016, 2671, nr 2818, nr 2924, nr 3017.

Fond 146, opis 50, nr 1492.

Fond 146, opis 51a, nr 953a.

Fond 146, opis 66, nr 1673, $\mathrm{nr} 2011-2013$.

Fond 146, opis 84, nr 36, nr 46, nr 146, nr 2819, nr 3543-3546, nr 3547-3552, nr 3588-3593, nr 3591-3596, nr 3599-3601, nr 3602-3618.

Fond 160, opis 5 , nr 2429 .

Fond 187, opis 1, nr 2-4, nr 5, nr 6-12, nr 14, nr 15, nr 16 nr 17, nr 18-23, nr 43-76 i 47-48,

Fond 453, opis 1, nr 7, nr 16-21, nr 20, nr 36, nr 37-41, nr 1190.

Fond 726, op 1, nr 1377.

\section{Opracowania:}

Bieś A.P., Jan Badeni (1858-1899). U początków ruchu spolecznego katolików w Galicji, Warszawa 1999.

Bieś A.P., Periodyzacja obecności Towarzystwa Jezusowego na ziemiach polskich. Struktury organizacyjne oraz oświatowo-edukacyjne i pastoralne formy aktywności, cz. 1, „Artykuły i rozprawy SPI” 2014, nr 17.

Chotkowski W., Powrót i ponowne zniesienie jezuitów w Galicyi 1820-1848 na podstawie archiwaliów rządowych, Warszawa 1904.

Cieślak S., Marcin Laterna SJ (1552-598). Działacz kontrreformacyjny, Kraków 2003.

Cieślak S., Działalność spoleczno-kulturalna jezuitów galicyjskich w stowarzyszeniach katolickich 1856-1914, Kraków 2013.

Demkowicz A., Wypędzenie jezuitów z Imperium Rosyjskiego na podstawie fragmentów Wygnańca z Białej Rusi Jana Galicza, „Tematy i Konteksty” 2012, R. 2(7).

Encyklopedia wiedzy o jezuitach na ziemiach Polski i Litwy (1564-1995), oprac. L. Grzebień przy współpracy zespołu jezuitów, Kraków 1996.

Grzebień L., Konwikt szlachecki we Lwowie w l. 1842-1848, [w:] Jezuicka ars educandi. Prace ofiarowane Księdzu Profesorowi Ludwikowi Piechnikowi SJ, red. M. Wolańczyk i S. Obirek, Kraków 1995.

Grzegorz Piramowicz i jego epoka, red. K.A. Boreczek i A.A. Witusik, Kurów 2001.

Kajdański E., Michał Boym - Ambasador Państwa Środka, Warszawa 1999.

Kajdański E., Michał Boym - ostatni wysłannik dynastii Ming, Warszawa 1988.

Kościoty i klasztory Lwowa z okresu przedrozbiorowego, cz. 20 (2), oprac. A. Betlej, M. Biernat, M. Kurzej, J.K. Ostrowski, Kraków 2012.

Kramarz H., Jezuici we Lwowie na przestrzeni wieków (zarys faktografii i perspektywy badawcze), [w:] Jezuici a kultura Polska, Kraków 1993. 
Kumor B., Powrót jezuitów do Galicji, „Folia Historica Cracoviensia” 1994, vol. 2.

Leń K., Jezuickie kolegium św. Jana w Jarosławiu 1573-1773, Kraków 2000.

Łuszczak G., Nauczyciele i wychowawcy szkót jezuickich we Lwowie 1608-1773, Kraków 2010.

Materyaly do dziejów Akademii Połockiej i szkót od niej zależnych, zebrał L.G., Kraków 1905.

Obirek S., Jesuits in Poland and Eastern Europe, [w:] !e Cambridge Companion to the Jesuits, red. T. Worcester, Cambridge 2008.

Obirek S. Jezuici w Rzeczypospolitej Obojga Narodów w latach 1564-1668: działalność religijna, społeczno-kulturalna i polityczna, Kraków 1996.

Stolarczyk M., Udział duchowieństwa rzymskokatolickiego w galicyjskiej Wiośnie Ludów. Próba charakterystyki, [w:] Rok 1848. Wiosna Ludów w Galicji. Zbiór studiów, red. W. Wic, Kraków 1999.

Sygański J., Święty Stanistaw Kostka, Lwów 1906.

Załęski S., Jezuici w Polsce, t. 1-5, Kraków 1900-1906.

Załęski S., Jezuici w Polsce, w skróceniu 5 tomów w jednym, z dwoma mapami, Kraków 1908.

Załęski S., Kolegium jezuickie w Stanisławowie. Szkic historyczny, Nowy Sącz 1896.

Załęski S., Kościół oo. Jezuitów we Lwowie pod wezwaniem śś. Apostołów Piotra i Pawła, Lwów 1879.

Załęski S., OO. Jezuici we Lwowie, Lwów 1880.

Инглот М., Общество Иисуса в Российской Империи (1772-1820 гг.), его роль в повсеместном восстановлении Ордена во всем мире, Moskwa 2004.

\section{Magdalena Ujma}

\section{LEGACY OF THE JESUITS IN THE RESOURCES OF THE CENTRAL STATE HISTORICAL ARCHIVES IN LVIV}

IN the resources of the Central State Historical Archives of Ukraine in Lviv, sources about the Jesuits concerns various parts of Galicia, and, in some cases, lands beyond its borders. Most archival units containing documents from the period of kasat are not widely known, and some of them are probably not used at all. The documents archived here may be of interest to art historians, as well as historians of material culture or medical historians. Part of them may prove useful also in research on pre- and fortune-possession of Jesuits in the Austrian Partition and outside its borders. The wide chronological range and the abundance of this material lead to the conclusion that it well reflects the subsequent stages in Jesuit history after the dissolution of the order in 1773. Many documents relate to just this and the period before and after the restoration of the Order in 1814 . His delegalization in 1848 and the way of the Jesuits to abolition in 1853 are well documented. Preserved inventories don't have to be fully reliable, of course. They may also not reflect the actual possession of the order in the period before the dissolution. The important thing is, that they allow at least a partial reconstruction of the equipment of churches, colleges, pharmacies or convents. These documents also contain lists of monks and a discussion on providing them with means of subsistence. Thanks to them, we also get a spatial picture of the development of post-Jesuit plots, gradually merging into the urban organism modernized in the $19^{\text {th }}$ century.

Keywords: Jesuits, Lviv, cancel, monasteries. 